\title{
Creative Marketing Strategies of Sembung Batik
}

\author{
Ririn Puspita Tutiasri ${ }^{1}$,Syafrida Nurrachmi Febriyanti², \\ Ahmad Fahri Huzain ${ }^{3}$, Abizard Sakti Nugroho ${ }^{4}$
}

\footnotetext{
${ }^{1}$ Communication Studies Department, Universitas Pembangunan Veteran, Jawa Timur

${ }^{2}$ Communication Studies Department, Universitas Pembangunan Veteran, Jawa Timur

${ }^{3}$ Communication Studies Department, Universitas Pembangunan Veteran, Jawa Timur

${ }^{4}$ Communication Studies Department, Universitas Pembangunan Veteran, Jawa Timur Corresponding Author's Email: ririn_puspita.ilkom@upnjatim.ac.id
}

\begin{abstract}
Batik is one of the cultures that is owned by the Indonesian. Batik describes a story in a piece of cloth, about certain events and symbols that are referred to as patterns. Each region has its batik style as a characteristic and differentiator from the other regions. Basically, batik has the same technique, which is to close and draw pictures or patterns and color them. Yogyakarta is famously identified with batik. Therefore batik business magnificently develops in this city. Today's era encourages innovation in making batik is necessary, especially digital marketing, so the products are not only sold in galleries. Some home industry businesses in the city of Yogyakarta have used digital promotion strategies, one of which is Batik Sembung. The data of this research was collected through observation and in-depth interviews. The results of the Batik Sembung digital promotion analysis on social media accounts are to promote the products online. Besides, the presence of online services eases for customers to choose the desired product quickly. In addition, social media also facilitates the owner to introduce new products or new creations and also eased the customers to see the style, color, and fabric that will be selected. Thus, customers do not need to come to the batik Sembung gallery. In digital promotion strategy, the batik home industry uses social media such as Facebook and Instagram, where both social media focuses on images and writing. Batik Sembung home industry can display the latest creations in more detail way and show creativity in styles and patterns.
\end{abstract}

Keywords: creative industry, digital promotion, Batik Sembung

\section{INTRODUCTION}

Today, the batik industry is an interesting thing to study, where many people are re-interested in traditional culture. Traditional culture is no longer something that has passed, but something that has historical significance because it contains values and symbols. Batik is one of the traditional cultures that still exist in the midst of the development and progress of the era. Batik is still believed to have more value in each stroke and color, has a certain meaning. Not just a colored fabric with a motif on it. The traditional value of batik is very interesting because the more traditional process of making, namely with canting and night, not with stamp or printing, makes more value on the fabric. Although 
almost the same every batik cloth has a unique symbol, attractive, and has a different selling price. Many batik creative industries package batik in their way, where the owners of the industry want to have the inherent uniqueness of their products.

Indonesia almost has a batik typical in ever region, although with different fabrics, different colors, but in essence, the same cloth covering and giving the color or technique of dyeing. Each region is distinguished by its style and color, as a characteristic of their respective regions. The difference between one region and another makes batik an attractive creative industry. Each region needs to develop its regional characteristics into something interesting. In addition to the accuracy and patience of the batik process, creativity is also needed in making batik motifs, especially for contemporary batik. Many home batik industries make batik creations as a form of creativity and as a characteristic of the industry. Contemporary batik is the batik of the maker where the maker is not in accordance with the standard. The motive has no symbolic meaning; the variety is free and broad even in addition to animal and plant motifs there are also abstract motifs and are not related to an area. Unlike the classic batik where there is a standard in the making, each style has meaning, the motifs that exist in batik tend to be related to a particular area or are characteristic of an area.

The batik industry has grown even more since the endorsement of batik became Indonesia's cultural heritage on October 2, 2009; there appeared a wide variety of batik motifs. Contemporary batik is attractive because the colors are brighter, and the motifs are diverse, making the batik industry attractive because it is more colorful and rich in motifs. In addition to requiring creativity in contemporary motifs, it is also necessary to have an appropriate marketing strategy for its products, making the batik industry develop rapidly. Batik marketing must also keep up with the times, which are not only centered on shops or traditional markets, but also through digital marketing. Many batik home industries do digital marketing by offering, but many are unattractive because the motifs or colors offered are only like those on sales posts. This makes the need for the creative industry in the batik industry. An attractive appearance on batik makes people interested in batik culture. Ancient times creative in batik can produce batik cloth in large quantities at low prices so that batik businesses appear stamped on cheaper batik fabrics; the existence of this batik makes batik prices affordable. Along with the development of the creative industry era is not only how to create batik quickly and at low prices, but also creates new creations, so that people and tourists are interested in and with the culture of batik. The creative industry in batik that is developing at this time is the existence of abstract batik, as well as the combination of printed batik with batik. Wherewith the creativity of batik makers is able to raise the selling value of batik, as well as to create a new culture, that is, people consider batik to have cultural value, not just a piece of cloth.

Many home industry batik marketing strategies that only rely on catalogs or rely on posts of batik products on social media. Directly, batik marketing is more crowded when sold because people can know the meaning of batik that he will buy, and feel the quality of batik cloth. In contrast to the batik home industry, 
Sembung, which combines direct marketing and digital marketing, it also establishes closeness with the public both directly and digitally. Building closeness directly is also done by promoting it online. From here, researchers are interested in examining how the digital promotion strategy carried out by batik Sembung.

\section{LITERATURE REVIEW}

Marketing

Marketing in the batik industry is needed to be able to compete with other batik industries. The entrepreneur must determine the goals and which the marketing targets are. According to Kotler (2008), marketing is a set of goals, objectives, policies, and rules that are the direction of the company's marketing efforts in dealing with the environment and the situation of competitors that are always different. Business owners must have a marketing goal that will be done in what way and can estimate the impact obtained when doing so.

In addition, determining the target market must also be the right to facilitate the product marketing process. To attract people, the business owner must have something different from the business competitors. In marketing must also see the needs, desires, and requests. Needs and desires are things that are similar but different, where the needs are when people have to have them, while the desires of the person do not need, but for some reason, he wants to have them. For example, people need cloth or batik clothes because at their place of work or place of study requires that he use batik on certain days, this makes the person's needs. While the desire where he already has a batik shirt that is used for the office or school, or he is not someone who has an obligation to wear batik, but when he saw the batik, he wants to have or feel the need to budget funds, buy a product. The creativity of the entrepreneur towards his product is able to create the needs and desires of the market. Needs and desires will affect increased demand.

Marketing is not only the process of moving goods or selling and buying goods but also the process of forming relationships with customers. Kotler and Armstrong (2015: 29) says marketing is a process of forming relationships with strong customers to capture the value of consumers in return and also the process of creating value for the customer itself. Closeness with customers needs to be created by business owners, to build relationships and trust. From here, the business owner or marketer will have loyal customers or create community groups that continue to buy products. The sustainability of a business is also determined by how many products it sells to the market.

\section{Marketing Strategy}

In marketing to get the right way, there needs to be a marketing strategy. Marketing strategies are used to simplify the way of marketing to reduce marketing expenses. Chandra (2002: 93), wrote a marketing strategy of the impact of the company's activities and expectations in product demand in the market in implementing the marketing plan. Mention is related to changing prices, 
advertising campaigns, designing special promotions, determining the choice of distribution channels, and so on. Determination of a good strategy will have an impact on product sales, where business owners can determine or change the price of the product when it starts to be marketed. namely:

Three strategies are carried out so that marketing can be maximized

1. So that buyers have the same response, then there is a determination of position in marketing strategies that place consumers in subgroups on the product market (Setiadi. 2003: 55). Identify who the marketing target is so that it is easier to carry out the marketing process. In the batik industry, it is very important to determine who the consumers are because it is related to the quality of batik products, as well as to the price of batik. In addition to determining consumers, there is also a need for a review of the target market

2. To deciding consumers, there is also a need to examine target markets and evaluate them by examining three factors (Umar, 2001: 46):

a. The size and growth of the segment

b. Structural victory in segments

c. Objectives and resources

3. The existence of market reviewers and evaluating can estimate how far the product can be accepted and compete with whom

4. The existence of a strategy to build trust, confidence, and competence for customers, namely the strategy of determining the target market and positioning the market (positioning). Product positioning needs to be done so that it is accessible to the market, where consumers will know the advantages or disadvantages of the product.

To be able to compete, every batik business must have a different and attractive marketing strategy, making it has its characteristics. It is also able to evaluate the weaknesses and opportunities that exist, wherefrom this evaluation will be found ways, and how to improve the deficiencies that exist. With the determination of the right marketing strategy, marketing communication, or integrated marketing communication is also needed. With integrated marketing communication, it can determine potential customers by integrating planning, manufacturing, integration, and implementation of how to market products.

\section{Integrated Marketing Communication}

In integrated marketing communication, there is a process of communication-related to the planning, manufacturing, integration, and implementation of many forms of marketing communication (advertising, sales promotion, publicity, events, etc.) It is carried out continuously on the intended customers and other potential customers (Shimp, 2010: 10). The existence of integrated marketing communication can maximize the way of marketing a business by maximizing the elements of marketing communication.

In marketing communication. In the communication mix. Kotler \& Armstrong (2011: 405) mentions the promotion mix is a combination of promotional tools consisting of advertising, public relations, direct marketing, 
personal selling, and sales promotion that companies use to convince consumers and build relationships. While Morrisan M.A (2010: 17-34) promotion mix consists of 6 types, namely:

1. Advertising

2. Direct Marketing

3. Sales Promotion

4. Public Relations

5. Personal Selling

6. Interactive / Internet Marketing

By conducting integrated marketing communication, it is expected that the marketing process can be maximized.

\section{Digital Marketing}

The development of the sophistication of communication technology also affects the way of marketing communication. Ascharisa Mettasatya Afrilial (2018) mentioned the change in traditional or conventional marketing to be integrated into the digital world due to the technological revolution that occurred in the last few years. The existence of this digital media makes it easy for business owners to market their products where the transaction process does not have to occur face to face. The digital marketing process begins with: advertising, seller communication about products, ordering, transactions, and shipping. Dahiya \& Gaytri (2017) mentioned that internet connection is no longer a habit in marketing products and services. Besides, digital marketing is also safer for marketers when marketing to consumers. Hansen et al. (2004), consumers prefer to use online (online) with the consideration of risk rather than buying products conventionally or offline.

\section{METHODOLOGY}

In this research, the method used is a descriptive qualitative research technique. Researchers use this research technique to explain phenomena through in-depth data collection. The main problem raised by researchers is knowing how the Digital Promotion Strategy, Sembung Batik Home Industry. With this method, researchers can get in-depth and comprehensive results. Qualitative research methods aim to understand phenomena in social contexts. Moleong (2002: 3) says promoting the process of deep communication interactions between researchers with the phenomena under study. In this study, researchers conducted interviews with batik Sembung owners, employees in charge of conducting digital promotions, as well as direct observation, both the place of manufacture and marketing, as well as observing online marketing activities.

\section{RESULTS AND DISCUSSION}

The batik industry of Sembung, in its marketing combines digital marketing but also still promotes closeness with consumers. The creativity that is applied by the Sembung batik as a distinguishing feature with other batik namely on abstract batik which is rich in color, but also still preserves existing classic batik. The 
creation of batik creations is done so that people are interested in new nuances of batik. The following is the description of the owner of the Sembung batik:

"Batik sembung ciri khasnya kita. Batik abstrak yang kaya warna, yang kontemporer, yang keluar dari pakem, tapi kita masih membuat batik batik klasik, batik-batik pakem, batik yang dulu kita juga masih melestarikan, kan kita tujuannya itu untuk melestarikan budaya, karena kita juga melayani masyarakat, yang sudah jenuh pada batik monoton, lalu kita berkreasi membuat batik batik kontemporer, abstrak yang tidak meninggalkan motif motif lama. Dalam artian batik abstrak batik kontemporer tersebut masih ada motif-motif batik tempo dulu yang kita terapkan disitu, kombinasi".

"Batik is typical of us. Abstract batik has a lot of colors, contemporary that comes out of the standard. However, we still make classic batik, standard batik, batik that we used to preserve still. Our goal is to preserve culture because we also serve the community, which already saturated with monotonous batik. We are creative in making contemporary, abstract batik that does not leave old motifs. In the sense of abstract batik contemporary batik, there are still batik motifs that we applied there, the combination".

The Sembung batik market share is not only local, but national and international, from other countries such as America, Japan, Finland and India. In addition to making contemporary, abstract or classical motifs, Sembung batik also serves batik making from other regions, as revealed by the Sembung batik owner:

"Kalo dia sekedar membeli, dia ambil apa yang sudah ada motif kita dibeli, tapi kalau dia bener-bener pengen membuat batik ciri khas daerahnya, dia membawa kesini, lalu kita buatkan ya"

"If he just buys, he takes what we already have motives bought, but if he wants to make batik typical of his area, he brings it here, then we make it, yes."

In the service of making batik, the batik home industry serves consumers well. Where it serves the process of making classical batik, to maintain the values of classical batik typical of the city of Yogyakarta. It also serves the process of making batik from other regions so that batik is sustainable, as well as making the process of making abstract batik so that consumer choices become diverse and become a love of culture through batik. In the process of making batik Sembung already very skilled in their fields, understand what consumers want.

Batik Sembung business owners build closeness with consumers by building mutual trust. The quality of goods produced in accordance with the price of batik that has been determined. Buyers can buy batik directly in the goods display shop or buy through ordering on social media owned by Batik Sembung, such as Instagram, Facebook, and the website. After that, make a transaction at 
WhatsApp instant messenger. Trust is a value that is built not only when doing direct marketing, but also when doing media marketing. This is consistent with what was expressed by Kotler and Armstrong (2015: 29) that marketing is the process of forming relationships between sellers and strong customers, and the existence of value from consumers in return is also a process of creating value for customers. Marketing is not only a process of moving goods or services but also forming a relationship with customers.

\section{Sembung Batik Digital Marketing}

Not only in the manufacturing process, but it puts forward the belief in the marketing process also puts forward the trust. The owner is good, following the online marketing trend to widen market share, that is, not only in stores. Business owners analyze what social media are trending and fitting to do batik marketing; the following is:

"Karena banyak pengikut dan pemakai, pemakai Instagram dan Facebook kan banyak sekali, nah itu kan satu peluang kita untuk masuk ke situ”.

"Because there are many followers and users of Instagram and Facebook users, it becomes an opportunity for us to get in there."

The same thing was also said by employees who deal with batik Sembung's social media, which is following the trends in the community what social media are using, so they chose it. Here's what was said:

"Ya kebanyakan orang pengguna, menggunakan media sosial apa, kita menggunakan media itu”

"Yes, most people, what social media users, we use the media."

The choice of using social media to advertise on social media considers the number of people who use social media, as well as the culture of today's society. Where culture in society also influences the way of marketing, one of them is the culture of conducting transactions online. Transactions online are believed to facilitate buyers in purchasing an item. Hansen et al. (2004) state that consumers choose to use online media when making transactions due to the risks of conventional product purchases. Consumers have different types of choosing goods or services, so business owners must be able to convince the overall desires of the community with a marketing communication mix. Making the public aware of the goods being promoted, Morrisan M.A (2010) mentions six components in the marketing communication mix, namely: Advertising, Direct Marketing, Sales Promotion, Public Relations, Personal Selling, \&, Interactive / Internet Marketing.

In the marketing mix batik, Sembung conducts conventional marketing activities and through digital marketing. Even though conventional marketing activities are eventually uploaded to social media and strengthen digital marketing. Conventional marketing activities carried out, namely: marketing 
activities that are personal selling, i.e., there are people who come to the batik sales gallery or the place of making batik. Participating in exhibitions or fashion shows, as well as batik workshops. Batik workshop activities in collaboration with tour guides who bring domestic and international tourists to learn the process of making batik. With this conventional marketing activity, batik owners build trust and build closeness with visitors who are ultimately interested in becoming customers. With conventional marketing or offline consumers can ask questions and feel the batik cloth sembung,

"Kalau offline, di galeri kan kita bisa liat, pegang kainnya, bisa wawancara panjang lebar"

"If it's offline, in the gallery, we can see it, hold the fabric, we can interview at length."

The batik owner graciously serves every person who comes to his house or place of batik making, permits viewing, even tries to make batik. Placement of a separate batik sales gallery also makes there no pressure to buy batik products when visiting the place. This atmosphere is interesting, where visitors feel close to the owner of the batik. Conventional activities carried out are uploaded to social media owned by Facebook, Instagram, and Website from Batik Sembung, to convince potential customers who view uploads on social media. Batik Sembung does advertisements using social media; batik owners have a reason why they use social media to advertise because they are closer to the product with the community. Like what is revealed as follows:

"Alasan ngupload foto ya? Karena ya mereka pada tahu batikbatik kita, kegiatan kita, ya dapat kepercayaan di masyarakat”

"Reasons to upload photos? Because they know about our batik, our activities, so we can trust the community."

Social media is a cheap medium for advertising; besides that, the public will also trust the products advertised through social media. A social media account is a representation of the account owner, making the account owner must be honest and trustworthy. Conversely, as potential customers, consumers can check whether the ads on social media are genuine or fraudulent from: a clear address (can be checked via digital maps), people's comments on the post, if the post is disabled, it should be suspicious, the number of followers of the account, as well as the price and quality of the goods advertised. Photo uploads on social media are also made interesting by introducing and displaying the creations of batik makers, both batik, abstract, a combination of abstract and written, contemporary writing, minimalist writing, stamp, stamp, and writing combination. It also displays a review of batik, which explains the description of the batik.

In online postings or digital marketing, Batik Sembung also shows the process of making, as well as details of batik patterns, colors, to the size of the fabric even including the address of making batik, 
"Dengan cara ya, kita mengupload nya gak hanya batik nya, tapi ya cara pembuatannya, terus dengan alamat sini yang lengkap".

"By the way, we upload it, not only the batik but yes, the way to make it, continue with the complete address here".

An interesting thing done by the online marketing team from Batik Sembung, namely the three media, both Facebook, Instagram, and Website are used as a place to display photos and information only, while transactions occur through WhatsApp instant messenger. Where consumers are advised to contact the admin to ask questions and transact via private chat. Where people who contact admin draw are people who are curious about the product, and people want to buy batik Sembung. However, most people contact the admin number via WhatsApp certainly buy,

"Kayaknya imbang deh mbak ya, mereka itu kebingungan, kalau ke WhatsApp pasti beli"

"It seems like a draw, miss, they are confused, if you go to WhatsApp, definitely buy."

Communicating with customers through the WhatsApp application creates relationships where customers trust more with the services performed. Besides uploading photos on social media, uploaded photos are not over-edited, where the admin is aware of customer satisfaction and disappointment. According to the admin of social media managers, this makes the customer more satisfied with the batik that was purchased when it arrived,

"Ngga terlalu ngedit kayak gitu, takutnya ya itu, antara fakta dan gambarnya beda, kalau terlalu banyak di edit”

"Not too much editing like that, afraid of that, between the facts and the picture is different if you edit too much."

Although marketing is done conventionally or online (digital), building trust with customers is necessary. Build trust by providing the same service. The existence of technological developments makes every business owner must be prepared to do digital marketing because the development of culture also influences how the marketing process.

\section{CONCLUSION}

The marketing communication carried out by the Batik Sembung industry is very creative and is able to make the Batik Sembung have its characteristics other than another batik. Marketing by selling directly to the batik gallery, marketing digitally using social media, participating in batik exhibitions, participating in batik competitions, and opening workshops in batik-making venues. In batik marketing communication, Sembung uses 
conventional and digital marketing where both are the same, namely how to build closeness and trust between marketers and customers. Building trust must be held where the marketing process is not just marketing and transactions but how to create good communication with customers.

\section{ACKNOWLEDMENT}

We would like to give my appreciate to Batik Sembung owner. Also Communication Department, Faculty of Social and Political Sciences. Universitas Pembangunan Nasional "Veteran" Jawa Timur. Indonesia

\section{REFERENCES}

A.Shimp, Terence. 2014. Komunikasi Pemasaran Terpadu dalam periklanan dan Promosi. Jakarta: Salemba Empat

Ascharisa Mettasatya Afrilia1. (2018). Digital Marketing Sebagai Strategi Komunikasi. Jurkom, Riset Komunikasi, 1(1), 147-157.

Armstrong, Kotler (2015), Marketing an Introducing Prentice Hall twelfth Edition, England : Pearson Education, Inc.

Chandra, Gregorius. 2002. Strategi dan Program Pemasaran. Yogyakarta: Penerbit Andi Ofset FE Ubaya dan Forum.

Dahiya, R., and Gayatri. (2017). A research paper on digitalmarketing communication and consumer buying decision process: an empirical study in the indian passenger car market. Journal of Global Marketing, 1- 23. http://dx.doi.org/10.1080/08911762.2017. 1365991

Hansen, T., Møller Jensen, J., \& Solgaard, H. S. (2004). Predicting online grocery buying intention: a comparison of the theory of reasoned action and the theory of planned behavior. International Journal of Information Management, 24, 539-550. https://doi.org/10.1016/j.ijinfomgt.2004.0 8.004

Kottler, Philip., dan Keller. Kevin lane. (2008), "Manajemen Pemasaran". Penerbit: Erlangga, Jakarta.

Morissan.2010.Periklanan: Komunikasi Pemasaran Terpadu. Jakarta:Prenada media grup

Moleong Lexy, 2002, Metode Penelitian Kualitatif, Bandung : CV. Remaja.

Setiadi, Nugroho J. 2003. Perilaku Konsumen: Konsep dan Implikasi untuk Strategi dan Penelitian Pemasaran. Jakarta: Kencana

Umar, H. 2001. Strategic Management in Action, Konsep, Teori, dan Teknik Menganalisis Manajemen Strategis Strategic Business Unit Berdasarkan Konsep Michael R. Porter, Fred R. David, dan WheelanHunger. Jakarta:PT Gramedia Pustaka Utama 